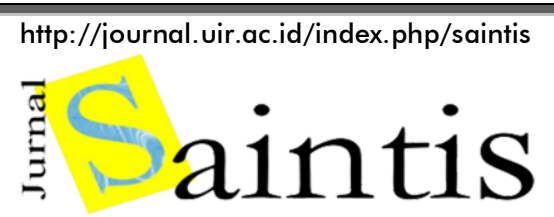

Volume 20 Nomor 01, April 2020 : 47-52

\title{
Penerapan Teknik Biocementation Oleh Bacillus Subtilis dan Pengaruhnya Terhadap Permeabilitas Pada Tanah Organik
}

\author{
Applicability of Biocementation Technique by Bacilus Subtilis and Its Effect of Permeability \\ in Organic Soil
}

Firman Syarif $1, *$, Gian Mahadika Davino ${ }^{2}$, Muhammad Ferry Ardianto ${ }^{2}$

${ }_{1}^{1}$ Program Studi Teknik Sipil, Universitas Islam Riau, Jalan Kaharuddin Nasution no 113, Pekanbaru, Indonesia

*Penulis korespondensi : firmansyarif@eng.uir.ac.id
Tel.: +62852-7178-1537; Fax.: -
Diterima: 12 April 2020; Direvisi: 24 April 2020; Disetujui: 26 April 2020.
DOI: 10.25299/saintis2020.vol20(01).4809

\section{Abstrak}

Indonesia memiliki persentase area rawa dan gambut yang sangat besar. Kurang lebih 30\% lahan di Indonesia adalah daerah rawa/gambut. Di Pulau Sumatera, Provinsi dengan lahan gambut terluas yaitu Provinsi Riau dengan luas $\pm 4,04$ juta Ha atau $56,1 \%$ dari luas total lahan gambut di Sumatera. Siak merupakan salah satu kabupaten di Riau yang memiliki daerah gambut yang cukup luas. Keberadaan daerah gambut ini menyebabkan pengembangan infrastruktur di Desa Suak Merambai menjadi terhambat karena tingkat kesulitan yang tinggi dalam proses konstruksi di daerah rawa. Beberapa metode perbaikan tanah telah diterapkan pada tanah gambut berupa perbaikan tanah secara fisik, mekanis maupun kimia. Salah satu metode perbaikan tanah yang mulai berkembang saat ini adalah Bio Grouting. Bio Grouting telah dikembangkan sebagai teknologi perbaikan tanah baru yang sistem kerjanya seperti semen pada beton sehingga mampu mengikat partikel tanah melalui bantuan aktivitas biologi. Bio Grouting ini dapat meningkatkan sifat mekanik (kekuatan, kekakuan, kohesi, gesekan), menurunkan permeabilitas bahan berpori, memperkuat atau memperbaiki dan memodifikasi sifat fisik dan mekanik tanah. Sistem kerja Bio Grouting adalah pengendapan Calcite oleh induksi microbiology, microbially induced calcite precipitation (MICP), yang dilakukan oleh bakteri penghasil enzim urease. Teknik microbially induced calcite precipitation (MICP) / Bio Grouting ini akan coba diterapkan pada tanah gambut sehingga dapat memperbaiki sifat permeabilitas dari tanah gambut. Melalui penelitian ini diharapkan permasalahan kontruksi diatas tanah gambut dapat diminimalisir dan menjadi salah satu solusi yang ramah lingkungan yang bisa membantu pengembangan infrastruktur di Desa Suak Merambai Kecamatan Bungaraya Kabupaten Siak Provinsi Riau.

Kata Kunci : Permeabilitas, Gambut, Calcium Carbonate Precipitation, Bio Cementation

\begin{abstract}
Indonesia has a very large percentage of swamp and peat area. About 30\% of the land in Indonesia is swamp / peat. On the island of Sumatra, the province with the most extensive peatlands is Riau Province with an area of $\pm 4,04$ million Ha or $56.1 \%$ of the total area of peatlands in Sumatra. Siak is one of the regencies in Riau which has quite extensive peat areas. The existence of this peat area causes the development of infrastructure in the Village of Suak Merambai to be hampered due to the high level of difficulty in the construction process in the swampy area. Several soil improvement methods have been applied to peat soils in the form of physical, mechanical or chemical soil improvements. One method of soil improvement that is starting to develop now is Bio Grouting. Bio Grouting has been developed as a new soil improvement technology that works like cement on concrete so that it can bind soil particles through the help of biological activities. Bio Grouting can improve mechanical properties (strength, stiffness, cohesion, friction), reduce permeability of porous materials, strengthen or improve and modify the physical and mechanical properties of the soil. The work system of Bio Grouting is the deposition of Calcite by induction of microbiology, microbially induced calcite precipitation (MICP), which is carried out by the bacteria producing the urease enzyme. This microbially induced calcite precipitation (MICP) / Bio Grouting technique will try to be applied to peat so as to improve the permeability of peat soil. Through this research, it is expected that construction problems on peatlands can be minimized and become one of the environmentally friendly solutions that can help infrastructure development in Suak Merambai Village, Bungaraya District, Siak Regency, Riau Province.
\end{abstract}

Keywords: Permeability, Peat, Calcium Carbonate Precipitation, Bio Cementation

\section{PENDAHULUAN}

Indonesia memilki lahan gambut seluas 20 juta hektar yang merupakan urutan ke empat setelah Kanada, Rusia dan Amerika dalam katagori lahan gambut terluas di dunia. Adapun penyebaran lahan gambut di Indonesia yaitu di empat Pulau besar yaitu Sumatera 35\%, Kalimantan 32\%, Sulawesi 3\% dan Papua 30\% [1]. Pada pulau Sumatera, lahan gambut biasanya terdapat di dataran rendah sepanjang pantai timur dengan luas 7,2 juta hektar. Di Pulau Sumatera, Provinsi dengan lahan gambut terluas yaitu Provinsi Riau dengan luas $\pm 4,04$ juta $\mathrm{Ha}$ atau $56,1 \%$ dari luas total lahan gambut di Sumatera [1].

[2] Menjelaskan bahwa, pada 18000 tahun yang lalu terjadilah pembentukan tanah gambut di Asia tenggara. Sedangkan gambut Indonesia terbentuk sekitar 5.000 hingga 8.000 tahun yang 
lalu. Tanah gambut ini terbentuk pada daerah yang telah lama terbenam air. Tanah gambut mempunyai sifat fisik maupun sifat teknis yang tidak menguntungkan bagunan sipil yang berada di atas tanah gambut akibat proses pembetukan tanah gambut tersebut. Sifat fisik tersebut antara lain kadar air (Wc) yang mencapai $900 \%$, berat volume tanah yang cukup kecil $\left(0,8-1,04 \mathrm{gr} / \mathrm{cm}^{3}\right)$, angka pori yang besar berkisar antara 5-15, dan kandungan organik yang tinggi $>75 \%$ [3]. Sifat fisik yang tidak menguntungkan tersebut secara otomatis mempengaruhi perilaku teknik tanah gambut. Tanah gambut mempunyai daya dukung yang sangat rendah $57 \mathrm{kPa}$ (Jelisic dan Lappanen, 2002) dan pemampatan yang besar dan tidak merata sehingga banyak bangunan sipil rusak akibat perilaku tersebut [3] [4].

Beberapa metode perbaikan tanah telah diterapkan pada tanah gambut berupa, perbaikan tanah secara fisik, mekanis maupun kimia. Salah satu metode perbaikan tanah yang mulai berkembang saat ini adalah Bio Grouting. Bio Grouting telah dikembangkan sebagai teknologi perbaikan tanah baru yang system kerjanya seperti semen pada beton sehingga mampu mengikat partiket tanah melalui bantuan aktivitas biologi. Bio Grouting ini dapat meningkatkan sifat mekanik (kekuatan, kekakuan, kohesi, gesekan), menurunkan permeabilitas bahan berpori, memperkuat atau memperbaiki bahan semen dan memodifikasi sifat tanah atau pasir. Sistem kerja Bio Grouting adalah pengendapan Calcite oleh induksi microbiology, microbially induced calcite precipitation (MICP), yang dilakukan oleh bakteri penghasil enzim urease [5],[7]Teknik microbially induced calcite precipitation (MICP) / Bio Grouting ini akan coba diterapkan pada tanah gambut sehingga dapat memperbaiki sifat fisik dan mekanik dari tanah gambut.

Permeabilitas Tanah adalah kemampuan tanah untuk mengalirkan air. Tanah dengan permeabilitas tinggi dapat meningkatkan laju infiltrasi, sehingga mengurangi laju air yang mengalir. Dalam ilmu tanah, permeabilitas didefinisikan secara kualitatif sebagai pengurangan gas, cairan atau penetrasi akar tanaman atau lewat. Selain itu, permeabilitas juga merupakan pengukuran konduktivitas hidrolik tanah. Pengiriman hidraulik tanah timbul dari keberadaan pori kapiler yang saling berhubungan satu sama lain. Konduktivitas hidrolik jenuh kuantitatif dapat diartikan sebagai kecepatan memindahkan cairan pada media berpori dalam keadaan jenuh. Dalam hal ini sebagai cairan adalah air dan sebagai media pori] adalah tanah [7],[8].

Permeabilitas adalah parameter tanah yang penting untuk setiap proyek di mana aliran air melalui tanah menjadi masalah, misalnya, rembesan melalui atau di bawah bendungan dan drainase dari tanah dasar atau penimbunan. Penelitian sebelumnya yang melibatkan perawatan biokementasi terutama difokuskan pada pengurangan permeabilitas media berpori tetapi masih belum teramati di tanah organik dan tanah liat [2] [3].

Pengendapan kalsium karbonat (CaCO3) yang diinduksi secara mikrobiologis adalah proses biogeokimia di mana pengendapan kalsium karbonat diinduksi dalam matriks tanah. MICP telah diusulkan sebagai teknik semen alternatif dan berkelanjutan untuk perbaikan tanah. Peningkatan kekuatan geser, kuat tekan bebas, kekakuan dan ketahanan likuifaksi telah dilaporkan karena presipitasi kalsium karbonat yang dihasilkan dari aktivitas mikroba. Mikrobially diinduksi kalsit (MICP) juga menawarkan solusi alternatif untuk berbagai masalah teknik sipil. Tes laboratorium menunjukkan bahwa MICP dapat melumpuhkan logam dan radionuklida melalui ko-presipitasi dengan kalsium karbonat. MICP juga telah terbukti meningkatkan respons geser tanah yang tidak terdrainase dan menawarkan manfaat potensial dibandingkan teknik peningkatan tanah saat ini yang dapat menimbulkan risiko lingkungan dan menderita "kepastian eksekusi" yang rendah [1].

Penerapan pengendapan atau penyemenan kalsium karbonat bakteri telah digunakan dalam berbagai aplikasi rekayasa geoteknik, seperti: perbaikan retakan pada granit dan beton, meningkatkan daya dukung tanah, pengisian poripori dan pengikatan pori-pori, serta mengurangi permeabilitas. Sebagian besar aplikasi biokementasi sebelumnya, bakteri yang disebut Bacillus pasteurii memainkan peran penting dalam presipitasi CaCO3. Ini menunjukkan produksi urease tinggi. Oleh karena itu, telah digunakan untuk sementasi kalsit mikroba dalam banyak penelitian [7] [8].

Teknik presipitasi mikroba yang diinduksi mikroba (MICP) / Bio Grouting ini akan diterapkan pada gambut sehingga dapat meningkatkan sifat fisik dan mekanik tanah gambut. Teknik ini menggunakan enzim urease untuk memisahkan urea menjadi ion amonium dan karbonat. Ion karbonat yang dihasilkan diendapkan sebagai kristal kalsit dengan adanya ion kalsium. Reaksi hidrolisis urea dan pembentukan kalsit ditunjukkan dalam Persamaan (1) - (3).

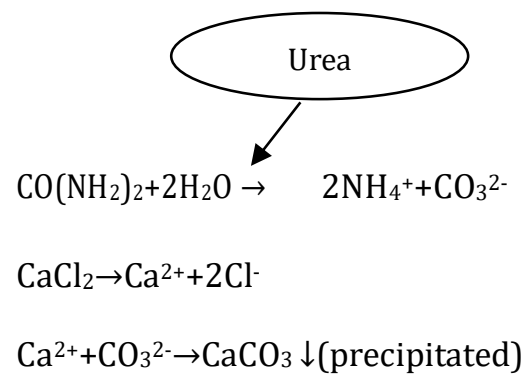


Permeabilitas adalah parameter tanah yang penting untuk setiap proyek di mana aliran air melalui tanah merupakan masalah yang memprihatinkan misalnya, merembes melalui atau di bawah bendungan dan drainase dari lapisan tanah bawah atau penimbunan. Dalam semua penelitian sebelumnya, teknik biocementation digunakan dalam upaya untuk meningkatkan sifat geoteknik tanah berpasir. Informasi dalam literatur tentang penerapan biocementation di tanah organik sangat terbatas. Studi ini berfokus pada penyelidikan penerapan presipitasi kalsit, dan pengaruhnya terutama pada sifat permeabilitas tanah organik. Organisme non-patogen Bacillus subtilis yang ditemukan secara alami di tanah dan limbah, digunakan sepanjang penelitian [8].

Dari uraian di atas, tujuan penelitian adalah: Sebuah studi awal untuk mengetahui seberapa besar pengaruh pencampuran larutan bakteri Bacillus Subtilis pada tanah organik yang stabil serta untuk mengetahui perubahan nilai parameter permeabilitas tanah organik dicampur dengan bakteri Bacillus Subtilis.

\section{STUDI LITERATUR}

Gambut merupakan tanah yang terbentuk dari bahan organik pada fisiografi cekungan atau rawa, di mana akumulasi bahan organik pada kondisi jenuh air, anaerob, menyebabkan proses perombakan bahan organik berjalan sangat lambat, sehingga terjadi akumulasi bahan organik yang membentuk tanah gambut. Di dataran rendah dan daerah pantai, mula-mula terbentuk gambut tipis (topogen), karena kondisi anaerobik yang dipertahankan oleh tinggi permukaan air sungai, kemudian penumpukan seresah tanaman yang semakin bertambah menghasilkan pembentukan hamparan gambut ombrogen yang berbentuk kubah (dome). Proses pembentukan gambut di daerah cekungan lahan basah seperti yang dikemukakan oleh [1] adalah sebagai berikut: (1) diawali dengan pengisian cekungan atau danau dangkal oleh vegetasi lahan basah (Gambar 2a), kemudian terbentuk gambut topogen yang berdekatan dengan tanah mineral (Gambar 2b), dan (3) pembentukan gambut ombrogen di atas gambut topogen (Gambar 2c) [5].

[2) Membagi tanah gambut menjadi 2 (dua) kelompok besar yaitu: tanah gambut berserat (fibrous peat) dengan kandungan serat mencapai $20 \%$ atau lebih dan tanah gambut tidak berserat (amorpous granular peat) dengan kandungan serat lebih kecil dari 20\%. Perilaku tanah gambut tidak berserat menyerupai tanah lempung sedangkan tanah gambut berserat mempunyai perilaku yang sangat berbeda dengan tanah lempung [3]. Pengujian laboratorium dan pengujian lapangan dilakukan untuk mengetahui sifat fisik dan teknis tanah gambut berserat sesuai dengan Peat Testing
Manual (1979). Tabel 1 menunjukkan sifat fisik hal pengujian laboratorium maupun lapangan. Berdasarkan Tabel diketahui bahwa parameter fisik dan teknis gambut.

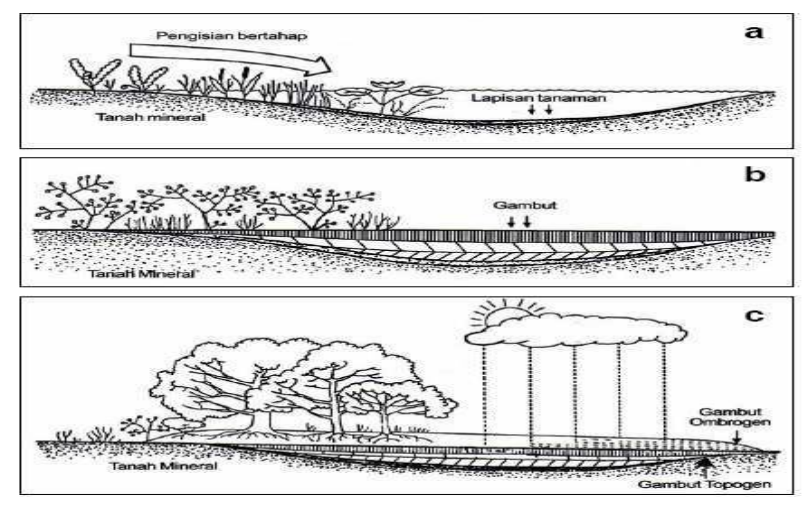

Gambar 1. Proses Pembentukan Gambut [3]

Konstruksi bangunan sipil di atas tanah gambut seringkali bermasalah akibat sifat fisik dan teknis tanah gambut yang buruk. Gambar 2 menunjukkan efek gambut pada konstruksi jalan yang mengalami penurunan yang tidak sama. Hal ini terjadi karena tanah gambut masih dalam kondisi initial (tanpa perkuatan) sehingga daya dukungnya rendah.

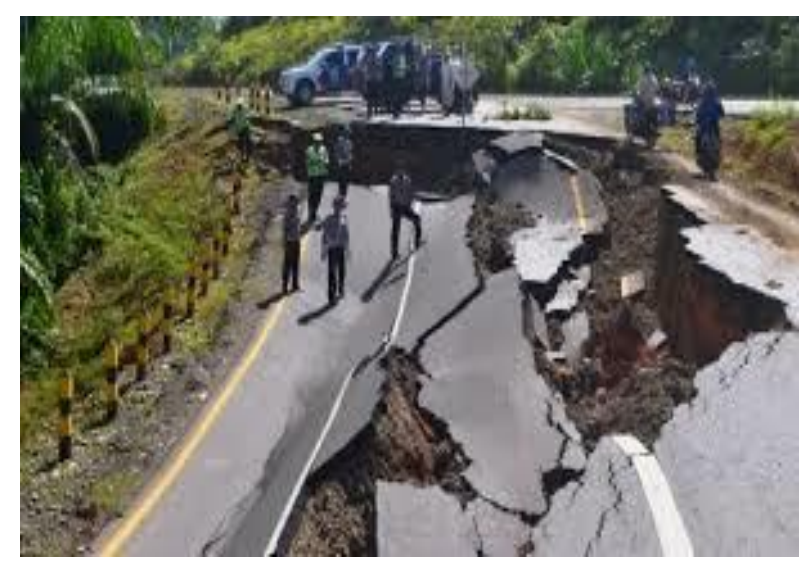

Gambar 2. Kerusakan Konstruksi Jalan yang Berada Diatas Tanah Gambut

Microbially Induced Calcite Precipitation (MICP) / Bio Grouting dikenal sebagai teknik perbaikan tanah telah dipelajari sebagai metode alternatif untuk meningkatkan sifat rekayasa tanah. Peningkatan kekuatan tekan bebas mulai dari 400 kPa hingga 1, $6 \mathrm{MPa}$ tergantung pada jumlah kalsit diendapkan tercapai dan permeabilitas dari sampel yang ditingkatkan berkurang lebih dari satu urutan besarnya [10]. Teknik ini menggunakan enzim urease untuk memisahkan urea menjadi ion amonium dan karbonat. Ion karbonat yang dihasilkan diendapkan sebagai kristal kalsit di hadapan ion kalsium. 


\section{MATERIAL DAN METODOLOGI}

Penelitian ini bertujuan untuk mempelajari pengaruh teknik Microbially Induced Calcite Precipitation (MICP) / Bio Grouting dalam sifat permeabilitas gambut, maka penelitian ini dilakukan dalam beberapa fase seperti terlihat pada Gambar 3 Diagram alir penelitian yaitu:

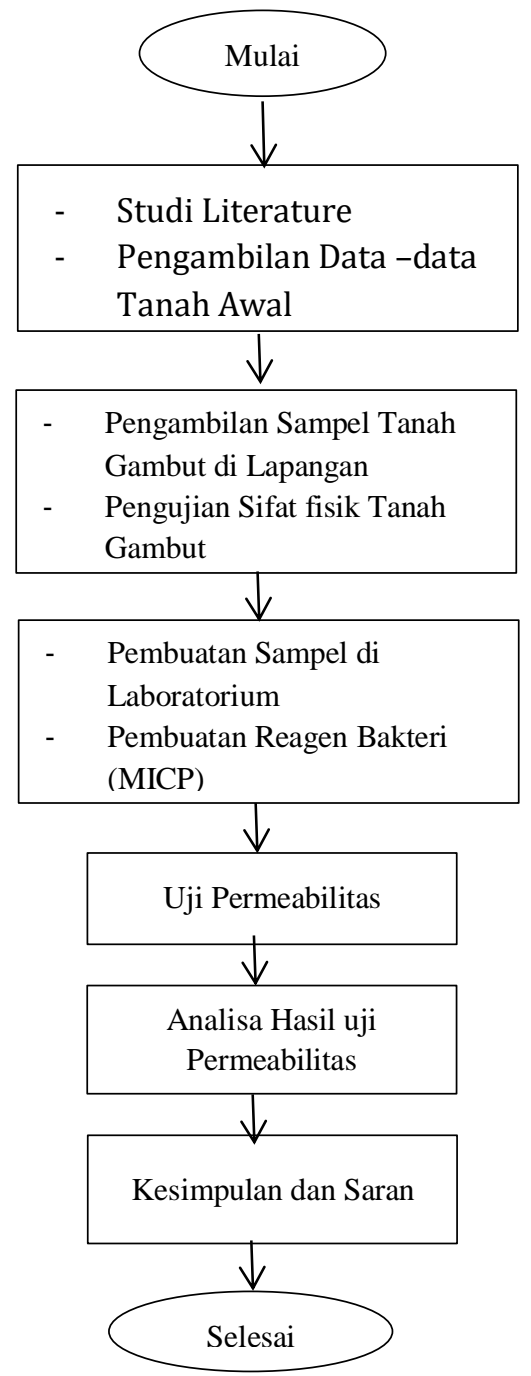

Gambar 3. Diagram Alir Penelitian

1. Studi literatur dari penelitian-penelitian terkait Konsep Microbially Induced Calcite Precipitation (MICP) / Bio Grouting telah diterapkan pada tanah pasir dan dapat memperbaiki sifat fisik dan tanah pasir oleh karena itu akan coba diterapkan pada tanah gambut.

2. Pengumpulan data-data awal

Data penunjang analisa seperti data sondir dan kekuatan tanah, stratigrafi tanah, lokasi muka air tanah, tingkat kadar air dan lain-lain akan di ambil melalui survey lapangan dan test di laboratorium. Data - data tersebut menjadi dasar untuk mengetahui sifat fisik awal dari tanah gambut sebelum di berikan perbaikan melalui Microbially Induced Calcite Precipitation (MICP) / Bio Grouting.

\section{Pengambilan sampel tanah}

Tanah gambut yang akan digunakan dalam penelitian ini diambil di desa Suak merambai kecamatan Bunga Raya Kabupaten Siak Provinsi Riau. Tanah gambut yang diambil adalah tanah undistrubed soil sehingga kondisi asli tanah tersebut di lapangan tetap dipertahankan.

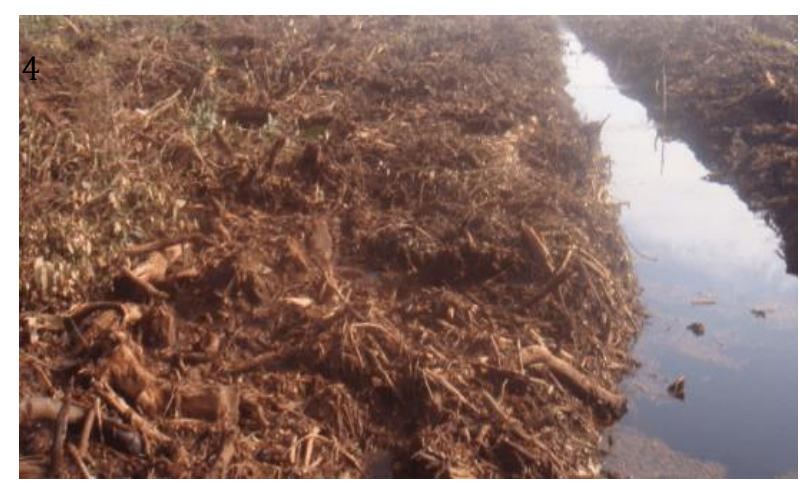

Gambar 4. Sampel Tanah Gambut

\section{Pembuatan Sampel di Laboratorium}

Tanah ini diklasifikasikan sebagai tanah $\mathrm{OH}$ terkait dengan Unified Soil Classification System (USCS) dan A-7-5 dalam sistem Klasifikasi AASHTO seperti pada Gambar 5.

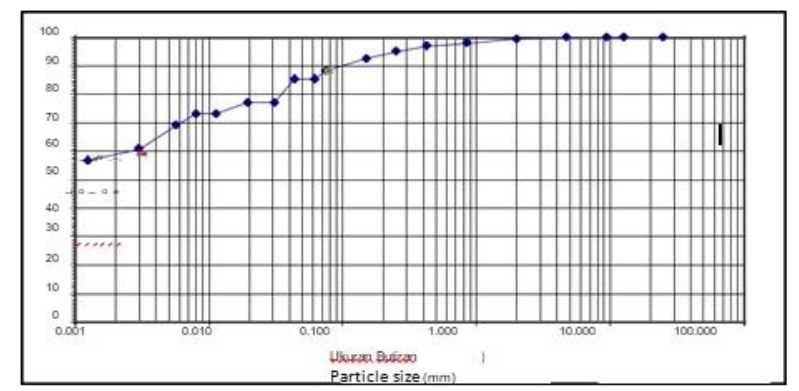

Gambar 5. Hasil Grain Size Distribution Dari Gambut

Dalam penelitian ini, pengendapan kalsit dievaluasi langsung dalam tabung polipropilena transparan (PP). Berbagai kombinasi reagen dan enzim dicampur secara menyeluruh dan dibiarkan bereaksi. Seperti yang terlihat pada skema pada Gambar 6, reagen dan urease disiapkan secara terpisah. Berbagai kombinasi urease dicampur secara menyeluruh dalam air suling selama 2 menit dan disaring menggunakan kertas saring (ukuran pori $11 \mu \mathrm{m}$ ) untuk menghilangkan partikel urease yang tidak larut. Purifikasi urease dan solusi reagen (yaitu, urea dan $\mathrm{CaCl} 2$ ) dicampur secara menyeluruh dalam tabung PP, dalam volume larutan total $30 \mathrm{~mL}$. 


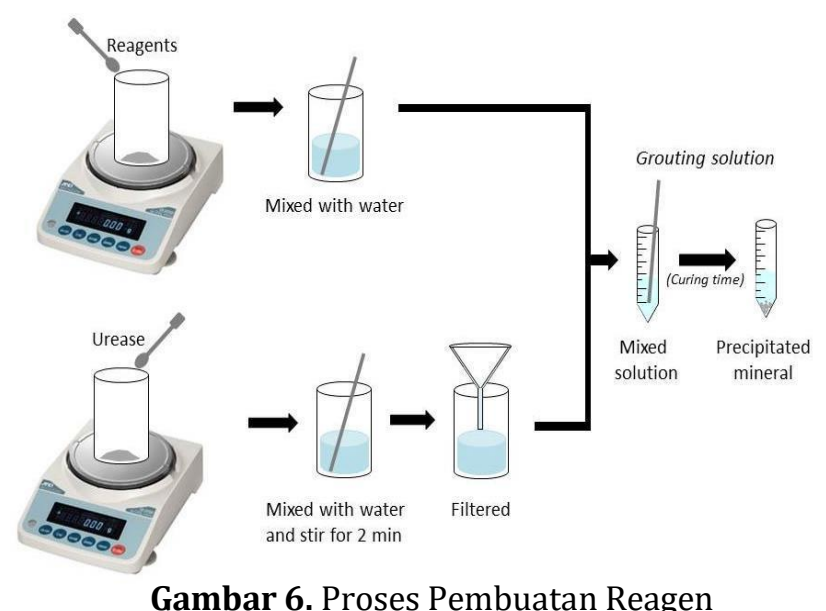

Dalam penelitian ini digunakan reagen yaitu CO (NH2) urea, CaCL2 dan Bacillus Subtilis sebagai bahan grouting. Penelitian ini adalah penelitian pertama untuk memastikan pengaruh teknik presipitasi kalsit yang diinduksi secara mikroba oleh bakteri bacillus cubtilis di tanah organik. Oleh karena itu, penelitian ini mencoba dengan jumlah konsentrat bahan yang acak dan membuat sampel dengan itu sebagai percobaan MICP. Konsentrat yang dibuat untuk reagen ada dalam tabel di bawah ini.

Table 1. Material yang Digunakan Dalam Reagent

\begin{tabular}{|c|c|c|}
\hline No & Material & Quantity \\
\hline 1. & Bacillus Subtilis & $5 \mathrm{gr}$ \\
2. & Urea ( CO(NH)2) & $10 \mathrm{gr}$ \\
3. & CaCl2 & $10 \mathrm{gr}$ \\
4. & Water & $20 \mathrm{ml}$ \\
\hline
\end{tabular}

Dalam penelitian ini digunakan $10 \%$ reagen yang dihitung dari berat tanah dan membuat perbandingan tanpa reagen pada sampel yang terlihat pada Gambar 7.

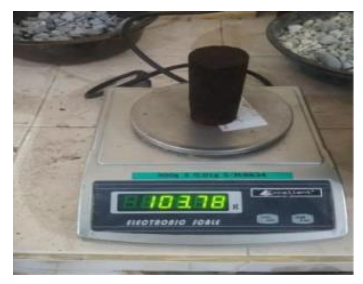

Gambar 7. Sampel yang Menggunakan Reagen

\section{Tes Permeabilitas}

Tes Permeabilitas bekerja dengan ASTM D 2343-68. Metode pengujian ini mencakup penentuan koefisien permeabilitas dengan metode head konstan untuk aliran air laminar melalui tanah granular. Prosedurnya adalah untuk menetapkan nilai-nilai representatif dari koefisien permeabilitas tanah granular yang dapat terjadi pada endapan alami yang ditempatkan di tanggul, atau ketika digunakan sebagai lintasan dasar di bawah perkerasan. Untuk membatasi pengaruh konsolidasi selama pengujian, prosedur ini terbatas pada tanah granular terganggu yang mengandung tidak lebih dari 10\% tanah yang melewati saringan $75 \mu \mathrm{m}$ (No. 200). Sampel tanah organik dengan reagen telah dimasukkan ke tabung uji permeabilitas dan kemudian air mengalir ke sampel dan membaca koefisien permeabilitas (k), lihat pada Gambar 8.
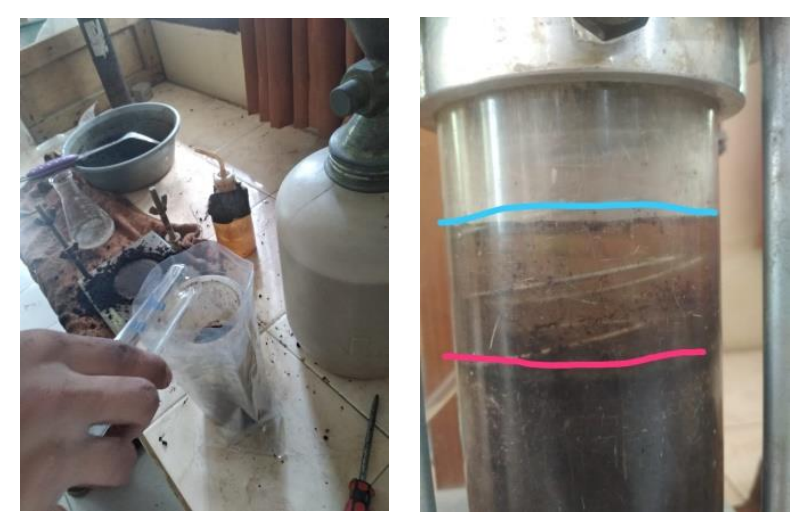

Gambar 8. Persiapan Uji Permeabilitas

\section{HASIL DAN PEMBAHASAN}

Dari hasil pengujian permeabilitas untuk kedua sampel didapat hasil seperti pada Gambar 9.

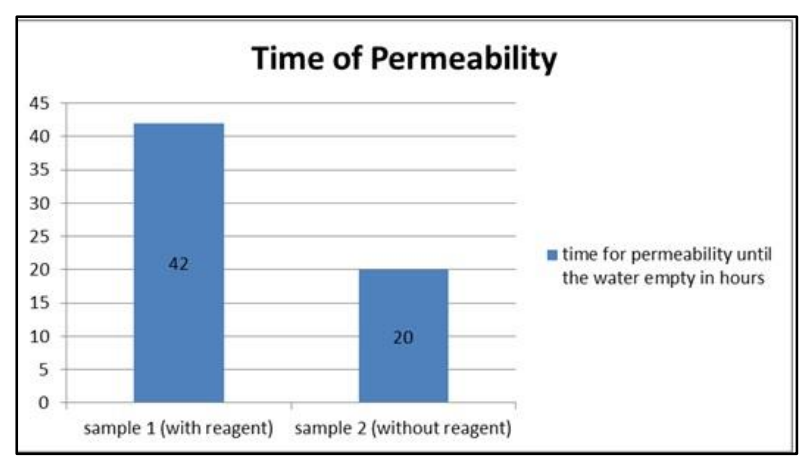

Gambar 9. Waktu Permeabilitas Untuk Kedua Sampel Tanah yang Dibuat

Dari hasil tes permeabilitas ditemukan bahwa sampel 1 (dengan Reagen) memiliki waktu yang lama untuk mengeluarkan air dari tabung/ permeabilitas lebih rendah dari pada sampel 2 (tanpa reagen). Hal ini disebabkan oleh penambahan bakteri Bacilus Subtilis yang dapat membuat pori-pori partikel tanah organik tertutup atau diisi bakteri sehingga tanah tidak mudah mengalir, tetapi ini harus diperiksa lagi menggunakan alat SEM (Scanning Electron Microscope).

Jumlah CaCO3 relatif lebih sedikit di tanah organik daripada di tanah berpasir [12]. Perbedaan dalam presipitasi kalsit dalam tanah organik dan tanah berpasir ini dapat dikaitkan dengan unsur organik yang larut dan bahan organik lainnya yang merupakan penghambat masuknya CaCO3 dan pertumbuhan kristal. Para peneliti telah 
menghubungkan mekanisme penghambatan ini dengan sejumlah faktor. Ketika molekul organik diserap ke permukaan mineral, mereka dapat menginduksi pembubaran atau mengganggu pertumbuhan kristal, tergantung pada kondisi saturasi [13],[14]. Studi lain telah mengusulkan bahwa kandungan bahan organik mencegah presipitasi CaCO3 dengan melapisi permukaan kristal CaCO3 yang ada, sehingga menghalangi situs nukleasi mereka dan mencegah pertumbuhan kristal homogen [12]-[15].

Selain itu, penyelidikan lebih lanjut harus dilakukan, untuk menganalisis manifestasi ini, yang meliputi efek air, $\mathrm{pH}$, dan jumlah karbonat. Selain itu, tanah organik memiliki kandungan air yang signifikan, dan karenanya harus dianalisis dalam penelitian selanjutnya.

\section{KESIMPULAN DAN SARAN}

\section{Kesimpulan}

Dari penelitian ini dapat diambil beberapa kesimpulan yaitu dengan campuran konsentrat yang dibuat sebagai reagen ini, tingkat Permeabilitas lebih rendah daripada dengan perawatan atau reagen apa pun. Selanjutnya, dalam penerapan teknik bio grouting di tanah organik harus dilakukan beberapa penyelidikan untuk memeriksa efek dalam teknik dan sifat fisik tanah organik.

\section{Rekomendasi}

Ada beberapa rekomendasi yang harus dilakukan dalam penelitian selanjutnya yaitu pertama periksa jumlah karbonat yang dibuat oleh reagen, kedua periksa dengan alat SEM efek dalam ikatan partikel tanah organik, dan yang ketiga investigasi pengaruh kadar air, $\mathrm{pH}$ dan aspek lain dalam keberhasilan Teknik grouting bio atau pengendapan kalsit yang diinduksi secara mikroba.

\section{DAFTAR PUSTAKA}

[1]. Wibowo, P. dan N. Suyatno.1998. An Overview of Indonesian Wetlands Sites -Wetlands International - Indonesia Programme (WI-IP).

[2]. Van De Meene (1984), Geological Aspects of Peat Formation in The Indonesian-Malyasin Lowlands, Bulletin Geological Research and Development Centre, 9, 20-31.

[3]. Mochtar, NE. et al. (1998), Koefesien Tekanan Tanah ke Samping At Rest (Ko) Tanah Gambut Berserat serta Pengaruh Overconsolidation Ratio (OCR) Terhadap Harga Ko, Jurnal Teknik Sipil, ITB, Vol. 5 NO. 4.

[4]. Sidik W, Canakci H, Kilic H I and Celik F 2013 Bakteriyel Kalsiyum Karbonat Olusumu Uzerinde Kumlu Zeminlerin Dane Capinin
Etkisi 5 Geoteknik Sempozyumu (Turkey: Cukurova Universitesi, Adana).

[5]. Mochtar, N.E. dan Yulianto, F.E. and (2017), Behaviour Change In Peat Stabilized With Fly Ash And Lime Caco3 Due To Water Infiltration, ARPN Journal o Engineering and Applied Science, Vol. 12, No. 17.

[6]. Mubekti. 2011. Studi Pewilayahan Dalam Rangka Pengelolaan Lahan Gambut Berkelanjutan Di Provinsi Riau. Jurnal Sains dan Teknologi Indonesia Vol. 13, No. 2, Agustus 2011 Hlm.88-94.

[7]. Barkouki et al (2011). Forward and Inverse Bio-Geochemical Modeling of Microbially Induced Calcite Precipitation in Half-Meter Column Experiments. Transp Porous Med (2011) 90: 23. https://doi.org/10.1007/s11242-011-9804z

[8]. Canacki et al (2014) Applicability of biocementation for organic soil and its effect of permeability. Geomechanics and Engineering, Vol. 7, No. 6 (2014) 649-663 DOI: http://dx.doi.org/10.12989/gae.2014.7.6.649

[9]. Putra et al (2017), Optimazitation Of EnzyimeMediated Calcite Precipitation For Soil Improvement Technique, Disertation, Ehime University, Japan.

[10]. Yulianto F.E. 2017. Perilaku tanah gambut berserat permasalahan dan solusinya. Konferensi Nasional Teknik Sipil dan Infrastruktur - I Jurusan Teknik Sipil Universitas Jember, 30 Oktober 2017.

[11].Lebron I and Suarez D L 1998 Kinetics and mechanisms of precipitation of calcite as affected by PCO2 and organic ligands at $25{ }^{\circ} \mathrm{C}$ Geochim. Cosmochim. Acta 62(3) 405-416.

[12]. Lin Y-P and Singer P C 2005 Inhibition of calcite crystal growth by polyphosphates Water Res. 39(19) 4835-4843.

[13]. Van Paassen L A, Daza C M, Staal M, Sorokin D Y, van der Zon W and van Loosdrecht M C M 2010 Potential soil reinforcement by biological denitrification Ecol. Eng. 36(2) 168-175.

[14]. Van Paassen L A, Ghose R, van der Linden T J M, van der Star W R L and van Loosdrecht M C M 2010 Quantifying biomediated ground improvement by ureolysis: large-scale biogrout experiment J. Geotech. Geoenviron. Eng. 136(12) 1721-1728.

[15]. Moeyadi $H$ et al 2013 Shear Strength Parameters of Improve Peat By Chemical Stabilizer Geotech Geol Eng 31(4) 1089-1106 (DOI 10.1007/s10706-013-9635-5. 